\title{
GLL
}

00

\section{ANALYSIS AND MODELLING OF TERRITORIAL VULNERABILITY TO EPIDEMIOLOGICAL DISEASES IN THE WILAYA OF BATNA (ALGERIA) - CASE OF TUBERCULOSIS}

\author{
Asma Douha, Mahdi Kalla
}

\begin{abstract}
Summary
Some epidemiological situations, because of their magnitude and their propagation dynamics, can escape local or national control. For example, the world is currently experiencing an uncontrollable cross-border spread of the corona virus (Covid-19). The Wilaya of Batna is among the most affected in Algeria by many epidemiological diseases, including tuberculosis, which raises questions about possible causal links between this contagious and often fatal disease and the environmental and socio-economic reality of this territory. We based our study on a number of factors, covering economic, societal and health aspects, which constitute indicators of the standard of living in each of the 61 communes of the Wilaya of Batna. The relationship between the epidemiological status of tuberculosis in these communes and these indicators showed significant correlations and thus confirmed the reliability of the choice of parameters of vulnerability to tuberculosis. To understand their interaction and impact on the disease and its spatial distribution, we used the hierarchical multicriteria analysis (AHP) method, the results of which were implemented in a GIS database. The aim was to provide health and territorial decision makers with a decision support tool. The results show that the spatial distribution of tuberculosis cases which reappeared in the Wilaya of Batna after its eradication since years is in good correlation with the socio-economic situation of each commune of the territory and confirm that this scourge of tuberculosis is closely linked to the degradation of the living conditions of the inhabitants.
\end{abstract}

\section{Keywords}

GIS • AHP • tuberculosis • environment • Batna • vulnerability

\section{Introduction}

Despite a permanent and continuous health watch in recent years, and despite previous advances in the field of prevention and treatment of epidemiological diseases, their eradication or control remains a difficult objective to achieve [Hoffner et al. 2018] because the geography of some epidemiological diseases, including tuberculosis, is largely correlated with that of underdevelopment [Furtado 2018, WHO 2019]. 
Tuberculosis is a contagious infectious disease [Yombi and Olinga 2015, Mao et al. 2019] caused by a mycobacterium of the tuberculosis complex, mainly mycobacterium tuberculosis [Mao et al. 2019, Bruce et al. 2020]. It occupies a prominent place in the major concerns of societies, and is always among the priorities of public health, due to its deadly and increasing characters [Van Vooren et al. 2010, Hoffner et al. 2018, Mathieu et al. 2019] and remains one of the ten leading causes of death according to the global reports of tuberculosis published by the WHO [Adeleke et al. 2020, Chakaya et al. 2021].

Its incidence varies considerably from country to country and population group to population group [de Castro et al. 2018]. All countries are affected, but most cases affect the most populous developing countries where the standard of living is sometimes reduced to the bare minimum such as India, Indonesia, China, Philippines, Pakistan, Nigeria, Bangladesh, and South Africa, which account for about two-thirds of the global total [de Castro et al. 2018, Mathieu et al. 2019, Chakaya et al. 2021].

Globally, this epidemic reveals still alarming figures, in 2016 its incidence 10.4 million new cases worldwide [de Castro et al. 2018, Vachon et al. 2018, Mao et al. 2019], and stabilized in 2017 to 2019 at about 10.00 million according to WHO data [Mathieu et al. 2019, Reyes et al. 2020, MacNeil et al. 2020, Chakaya et al. 2021], but it is still far from its eradication.

The increase in the number of tuberculosis patients is mainly in Africa, which produces the heaviest burden [Boulahbal and Chaulet 2004, MacNeil et al. 2020].

Algeria, one of the developing countries, remains classified by the World Health Organization among the group of countries with moderate prevalence of tuberculosis despite the long and well-administered national program to control this disease, with an annual incidence of between 20 and 99 cases per 100,000 people [Ifticene et al. 2015, Makhloufi et al. 2017]. The evolution curve knows a stabilization of the incidence in the form of a plateau from 2016 until 2018 with an average value of 52.2/100,000 inhabitants in 2018 [Mouhoub 2020].

Today, researchers agree to consider environmental and especially socio-economic factors as major determinants for tuberculosis, such as deteriorating socio-economic conditions, urban concentration with all the problems of poverty, promiscuity and household congestion, unemployment rate, aging population, high population density, lack of access to care programs [Boulahbal and Chaulet 2004, Van Vooren et al. 2010, Harling and Castro 2014, Pereira et al. 2015, Dangisso et al. 2015, Pelissari and DiazQuijano 2017, Aazri et al. 2020].

This research work focuses on the relationship and the epidemic-environment in the Wilaya of Batna, which is among the Algerian territories most affected by tuberculosis. It raises questions about the causal link through the analysis of vulnerabilities and their spatiotemporal articulation that explain the dynamics of the resurgence of this communicable disease. This involves linking the tuberculosis epidemic with the probable causes related to the physical and socio-economic environment of the territory [Taglioni and Dehecq 2009].

To access a multi-criteria spatial analysis of this epidemiological disease, we opted for the use of spatialization techniques through geomatics tools, in this case the imple- 
mentation of a digital database under GIS that allows a detailed analysis of the entities of the territory and their spatial-temporal articulation. These entities will define their attribute tables which must contain the elements of the environment having an impact or an influence on the epidemiological situation of this disease [Beale Linda et al. 2008].

\section{Description of the study area}

The Wilaya of Batna (Fig. 1) is located in the eastern part of Algeria (Northeast of the country) between the $4^{\circ}$ and $7^{\circ}$ of East longitude and $35^{\circ}$ and $36^{\circ}$ of North latitude. With an area of $12,038.76 \mathrm{~km}^{2}$, the territory of the Wilaya of Batna is almost entirely within a physical set consisting of the junction of the mountain chain of the Atlas Tellien in the North and the Atlas Saharien in the South, and this is what makes the main physical feature of the Wilaya, and thus determines the characters of the climate and the conditions of human life. Indeed, the Wilaya of Batna is characterized by a great climatic variability which strongly influences the general state of the environment. In general, the territory is characterized by a semi-arid climate with extreme seasonal variations in temperature and humidity [Kalla and Guettouche 2017, Baziz 2018].

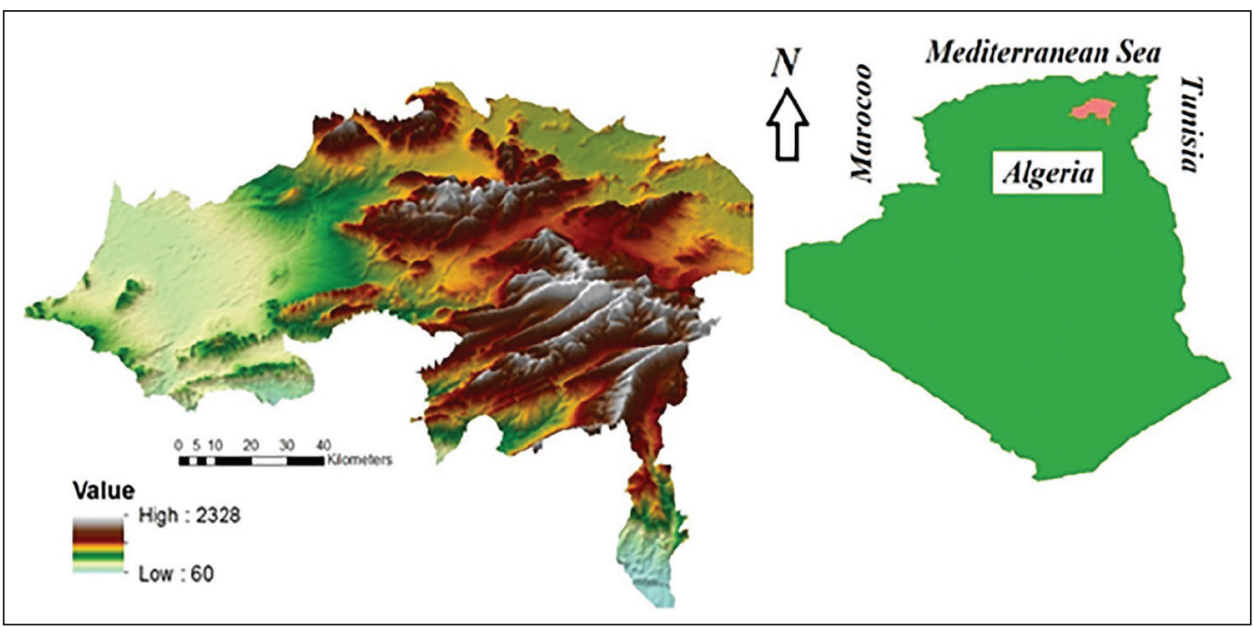

Source: Authors' own study

Fig. 1. Location of the study area

Administratively, the Wilaya of Batna currently has 21 daïras and 61 communes and is also considered one of the most populated territories in Algeria. The accelerated demographic growth of the Wilaya's population, marked by urban development in the form of poorly controlled sprawl generating great urban incoherence, are a factor of imbalance in the absence of viable economic growth and improved social conditions, particularly in terms of health. Given these conditions, it is not surprising that the 
Wilaya of Batna is distinguished from other regions of Algeria by a particular epidemiological situation in recent years [Kalla and Guettouche 2017, Baziz 2018].

\section{Materials and methods}

Based on the premise that tuberculosis is a disease that thrives in socially disadvantaged environments with all that these societal situations entail as factors of poverty and exclusion [Barrier 1994, Manneville 1995, Van Vooren et al. 2010, Pruvost and Rivalan 2014, WHO 2014, Amona et al. 2016, WHO 2018], we relied on a number of factors that reflect the modest nature of the standard of living in each of the 61 communes of the Wilaya of Batna.

The socio-economic factors related to poverty and the precariousness of the standard of living that results from it are numerous [Barrier 1994]. In our approach to modelling the level of territorial vulnerability to this disease, our choice was based primarily on the factors that we considered to be highly influential on the appearance of this disease and its development, and on the quantifiable nature of these factors.

It should be remembered that the most efficient models are those that incorporate a minimum of parameters and that best reflect the reality on the ground, since an excess of parameters often leads to systemic contradictions within the model. As it is difficult to evaluate exhaustively the standard of living of households in all 61 communes of the Wilaya of Batna, we opted for three types of parameters covering economic, societal and health aspects. The economic reality of the different communes was evaluated on the basis of official data relating to 'people without income' on the one hand and the 'level of state investment in small businesses' on the other hand, and their relationship with the sick people in the same territory. These are two indicators that provide information on the average standard of living in each municipality.

Moreover, since tuberculosis is a contagious disease [WHO 2014, Mao et al. 2019], compartmentalization and promiscuity in general create the most favorable conditions for the transmission of pathogenic bacteria and viruses. Therefore, we selected the parameter reflecting the average housing occupancy rate (TOL: Taux moyen d'Occupation du Logement), which is a widely used indicator in spatial analysis in land use planning.

Finally, we estimated that the level of health and medical care through the local medical entities in each territorial unit, in this case the commune, plays a more or less important role in the early diagnosis of the disease and in raising the awareness of the inhabitants of the risk of transmission [Barrier 1994], the precautions to be taken and the hygiene of life. For this purpose, we took into account the ratio between the number of people affected and the number of medical entities established in the commune and the ratio between the same people affected and the number of doctors practicing in this commune [Thébaud-Mony 1990].

In order to guarantee objectivity in the choice of these five factors and to integrate them as a parameter of the analysis model, we carried out a systematic correlation between each parameter and the population affected by tuberculosis (Fig. 2). The parameters whose correlation index is significant have been integrated in the analysis model. 

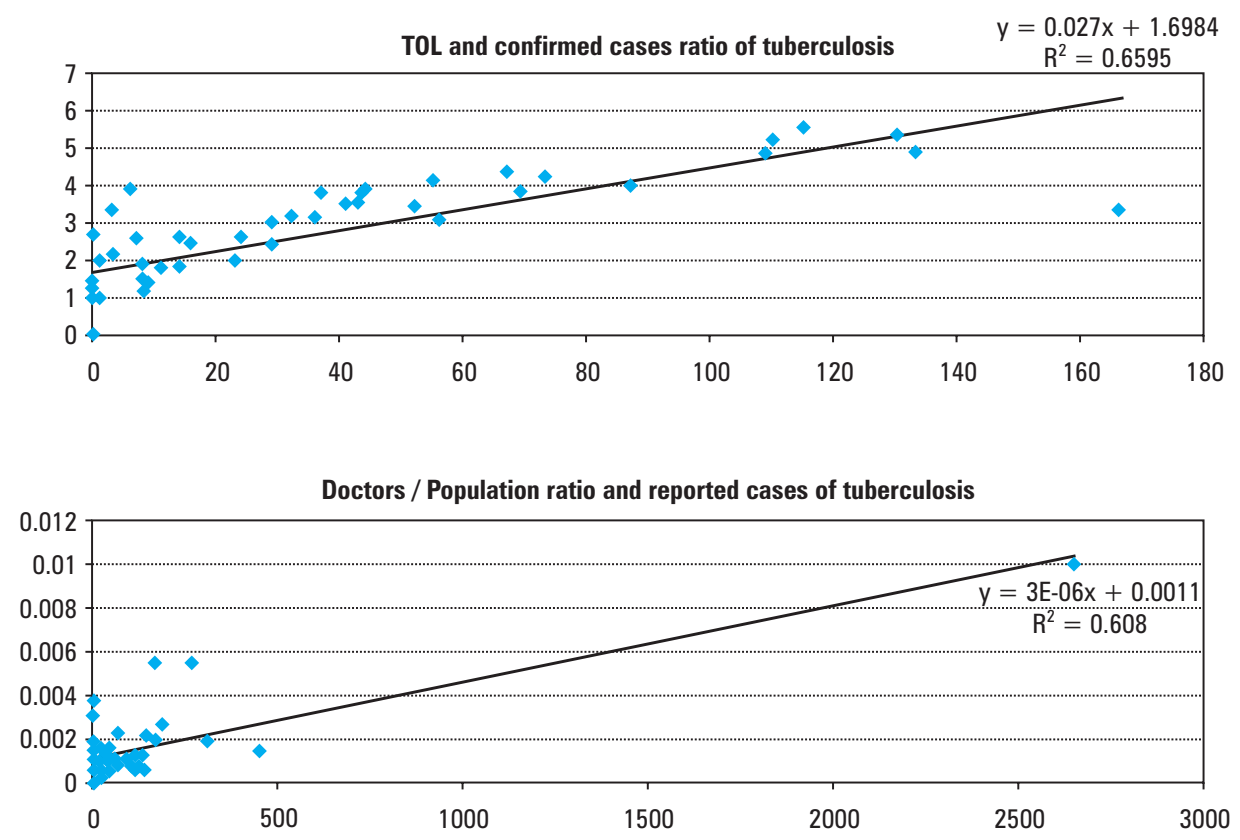

TB entities / reported cases of tuberculosis

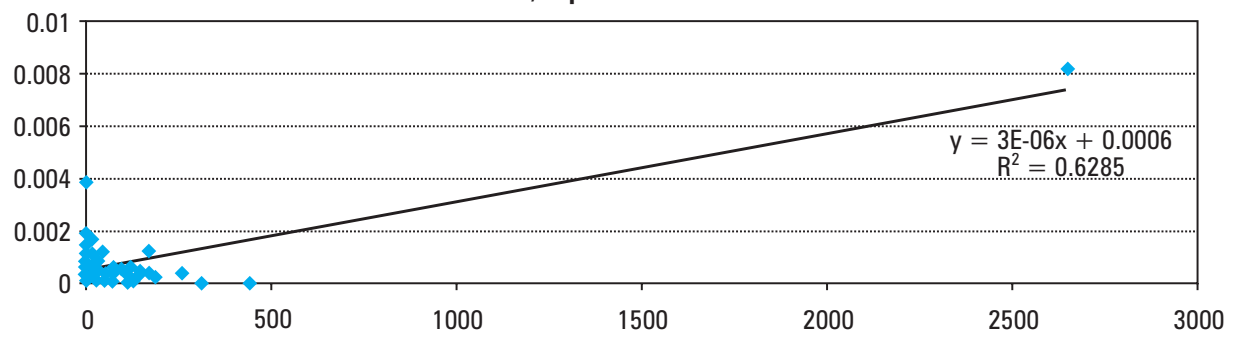

Ratio of no-income-people and reported cases of tuberculosis

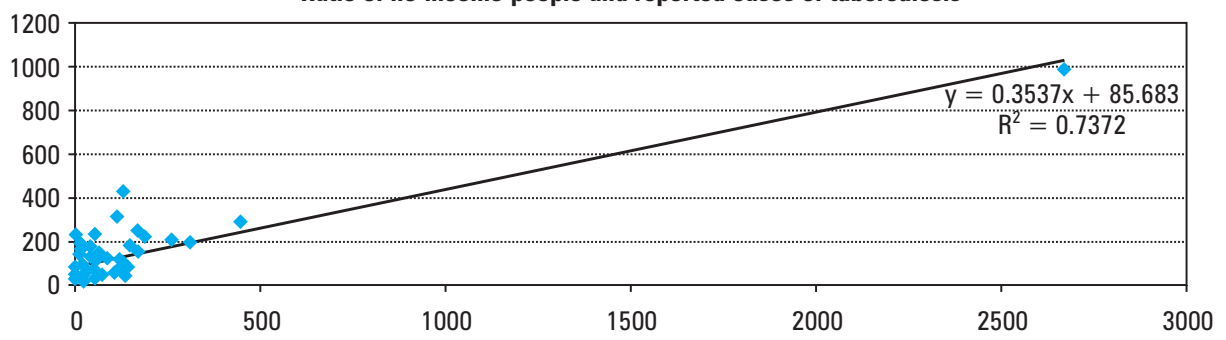

Source: Authors' own study

Fig. 2. Correlation between the several factors involved in the analysis with the number of reported cases of tuberculosis 


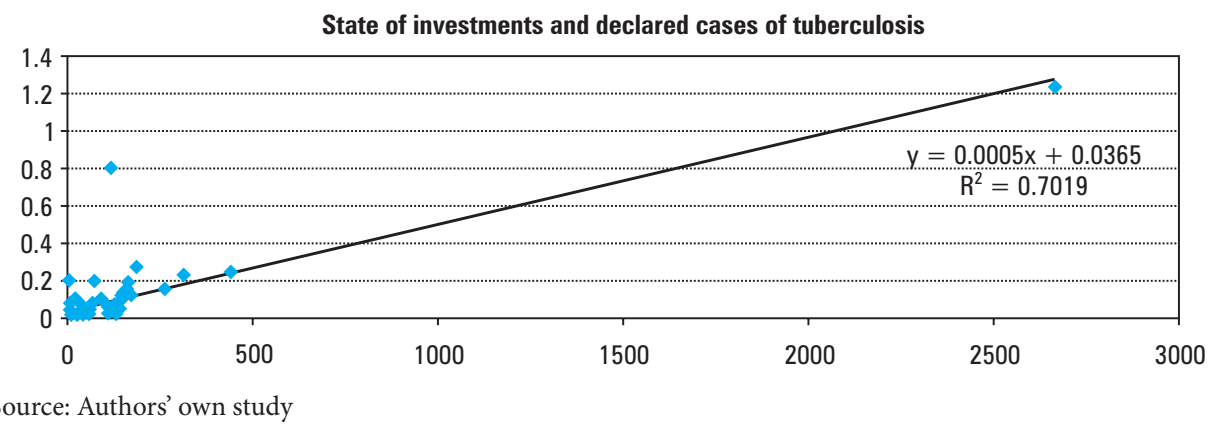

Fig. 2. cont.

All of these parametric data and all of those related to the geographical entities of all the communes, generated a considerable number of variables whose processing, analysis and mapping require the use of digital spatial analysis tools. We have implemented a GIS database under Arc Gis 10. 2.

The method of analysis adopted is that of AHP, Hierarchical Multicriteria Analysis. This method is initiated by the mathematician Thomas Saaty [Saaty 1987, Saaty 2008], is a method of multicriteria analysis that can be used in the quantification of qualitative characteristics, through its weighting. This hierarchical multi-criteria analysis method has presented reliability in the delineation of risk and its components according to several authors [Ramos et al. 2014, Siddayao et al. 2014, Elsheikh et al. 2015, Kacem et al. 2017, Rimba et al. 2017, Habibi et al. 2020].

Table 1. Nine-point pairwise comparison

\begin{tabular}{|c|l|l|}
\hline Importance & \multicolumn{1}{|c|}{ Definition } & \multicolumn{1}{c|}{ Explanation } \\
\hline 1 & Equal importance & Two elements contribute equally to the objective \\
\hline 3 & $\begin{array}{l}\text { Moderate } \\
\text { importance }\end{array}$ & $\begin{array}{l}\text { Experience and judgment slightly favor one parameter over } \\
\text { another }\end{array}$ \\
\hline 5 & Strong importance & $\begin{array}{l}\text { Experience and judgment strongly favor one parameter over } \\
\text { another }\end{array}$ \\
\hline 9 & $\begin{array}{l}\text { Very strong } \\
\text { importance }\end{array}$ & $\begin{array}{l}\text { One parameter is favored very strongly s and is considered } \\
\text { superior to another; its dominance is demonstrated in practice }\end{array}$ \\
\hline $2,4,6,8$ & $\begin{array}{l}\text { Extreme } \\
\text { importance }\end{array}$ & $\begin{array}{l}\text { The evidence favoring one parameter as superior to another is } \\
\text { of the highest possible order of affirmation }\end{array}$ \\
\hline
\end{tabular}

Source: Saaty [1987], Saaty [2008]

The factors are classified according to their levels of correlation with the number of reported cases of tuberculosis (Table 2). 
Table 2. Classification of factors according to their weight

\begin{tabular}{|l|c|}
\hline \multicolumn{1}{|c|}{ Factor } & Weight \\
\hline People without income & C1 \\
\hline Economic report & C2 \\
\hline TOL & C3 \\
\hline Healthcare Entities / Population ratio & C4 \\
\hline Doctors / Population ratio & C5 \\
\hline
\end{tabular}

After calculating the relative importance and determining the weight of each factor in the hierarchy, the tuberculosis vulnerability index is calculated according to the following formula:

Tuberculosis vulnerability $=0.437$ People without income + +0.302 Economic report $+0.142 \mathrm{TOL}+0.075$ Healthcare entities / Population ratio + +0.041 (Doctors / population ratio)

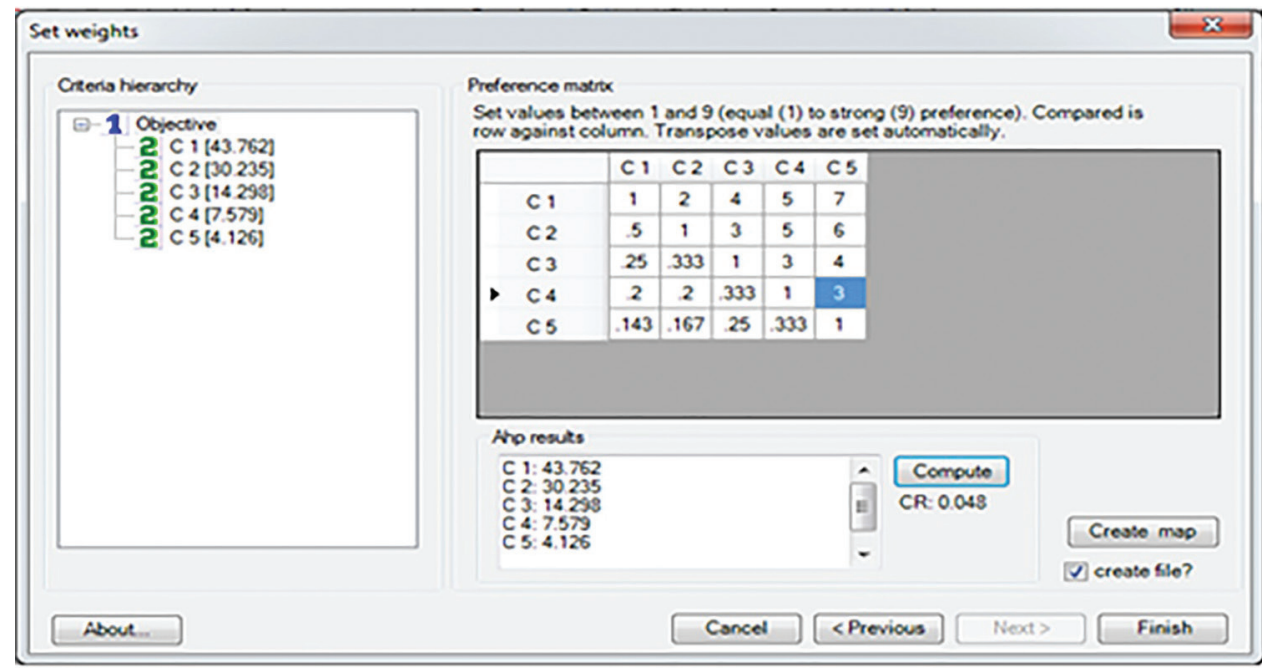

Source: Authors' own study

Fig. 3. AHP analysis under ArcGIS

Saaty considered a Coherence Ratio (CR) of less than 0.10 as acceptable; a higher ratio of the value 0.10 indicates a higher level of inconsistency [Ramos et al. 2014, Kacem et al. 2017, Fenniche 2018, Philippe et al. 2018].

In the case of our study, the $\mathrm{CR}=0.048$ and therefore the degree of consistency of the judgments is acceptable. 


\section{Results and discussion}

By examining the geographical distribution of reported disease cases and that of the general population, we find that the most populated municipalities are those that locate the most people affected by TB. Is there a significant dependency in terms of statistical correlation between these two sets of variables? (Fig. 4,5 ).

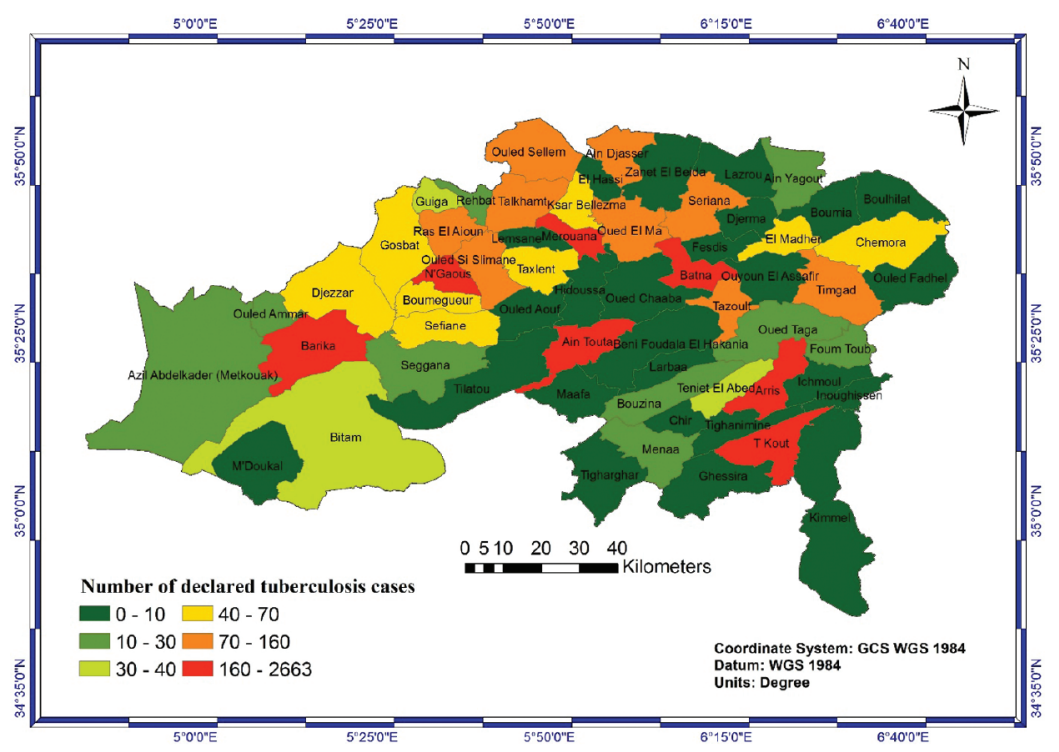

Source: Authors' own study

Fig. 4. Number of reported cases of tuberculosis in the Wilaya of Batna by commune

The answer is given by the results of the correlation (Fig. 6) which show that there is $70 \%$ of unexplained variance translating the absence of a significant functional relationship. So, if the number of patients is not related to the size of the population, it is logical to look for other elements of the territory whose nature and importance can explain the extent and the territorial spatial distribution of the disease.

By examining the causes of the resurgence of tuberculosis in the territorial of the Wilaya of Batna, the factors of vulnerability are subjected to the hierarchical multicriteria analysis (AHP) seem to observe some logic in their order in relation to their weight and their level of influence on the appeared of the disease (Table 2).

Indeed, the economic factor, and the ratio between the population of the municipality and people without resources receiving only some social help from the state and on the other hand the ratio between the population by municipality and the amount of state financing in term of investment in small businesses, represent $70 \%$ of influence of vulnerability. Next factor is the TOL (Taux moyen d'Occupation du Logement), this translates a situation that are often responsible for contamination risks [Amona et al. 
2016]. It should be noted, however, that the TOL is partly a result of economic factors because poverty necessarily result some precariousness in housing [Barrier 1994, Amona et al. 2016]. The factor related to the level of healthcare shows a modest level of influence compared to economic criteria.

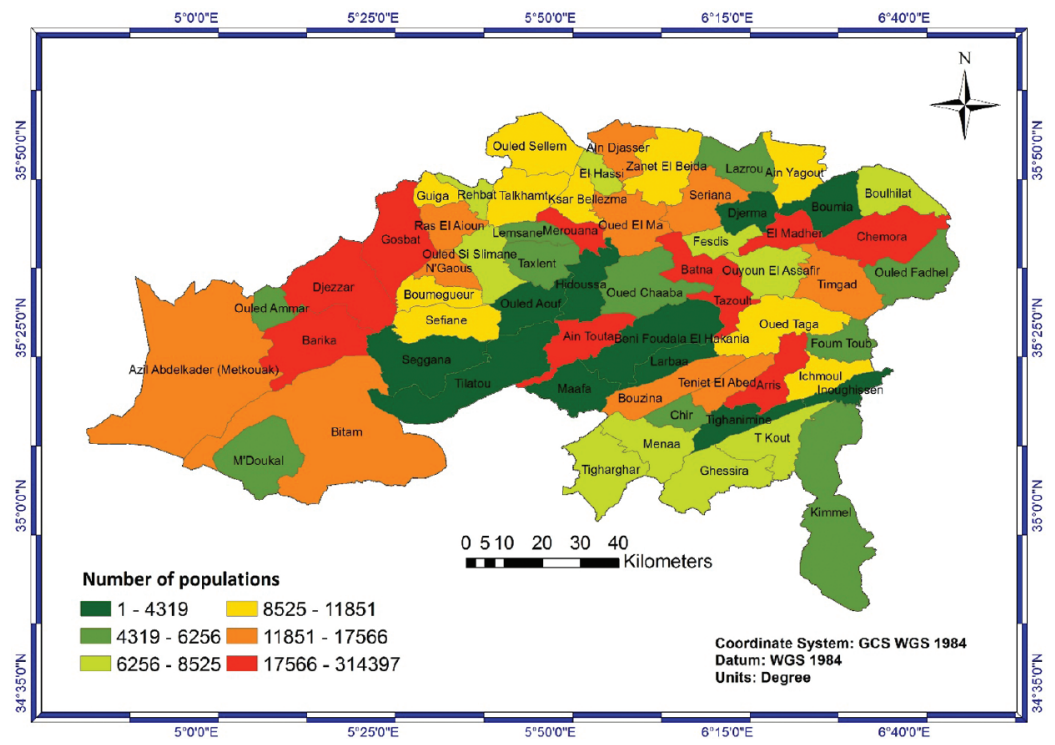

Source: Authors' own study

Fig. 5. Distribution of the population of the Wilaya of Batna by commune

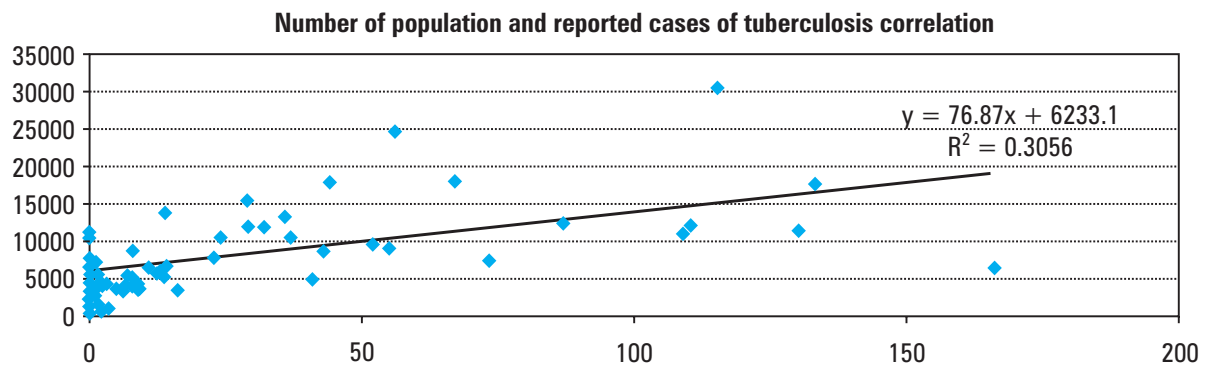

Source: Authors' own study

Fig. 6. Correlation: number of reported cases of tuberculosis with the number of populations

The different vulnerability parameters according to their value have been implemented in the GIS database. The spatial analysis conducted make it possible to draw up maps illustrating the situation of the numerous factors on the territory of the Wilaya (Fig. 7). 

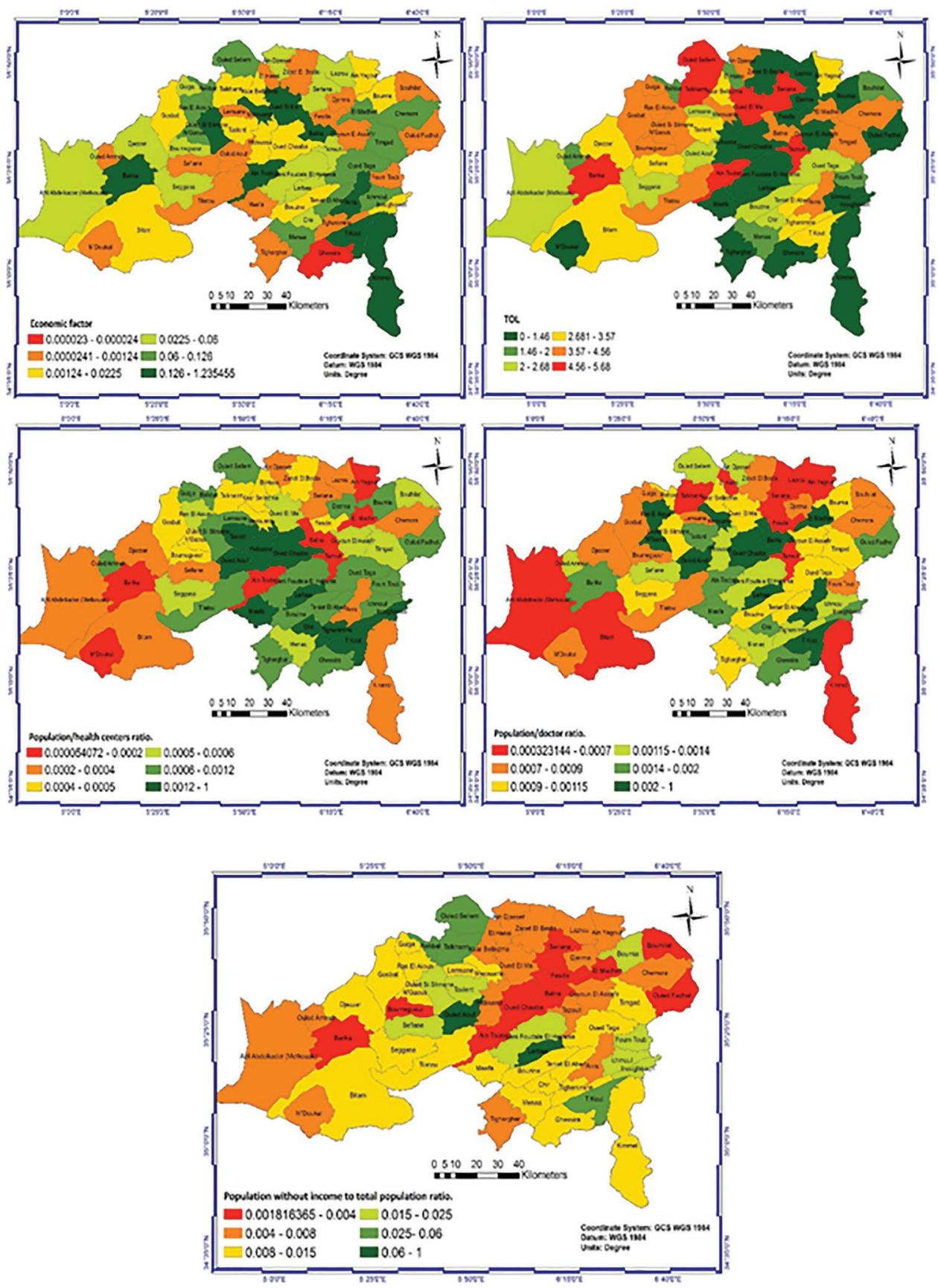

Source: Authors' own study

Fig. 7. Thematic maps of the factors involved in the analysis 
The previous analysis method shows that the territory of the Wilaya knows a disparity on the economic and societal level. Indeed, some of the chief towns of Wilaya and Dairy are more equipped with healthcare units and housing and receive more investment than others. This differentiation leads to an imbalance in the socio-economic level, and it will result various situations of vulnerability and significant levels of risk.

The multi-criteria analysis that we adopted, allowed us to draw up a synthetic map of the level of vulnerability on the whole territory of the Wilaya (Fig. 8).

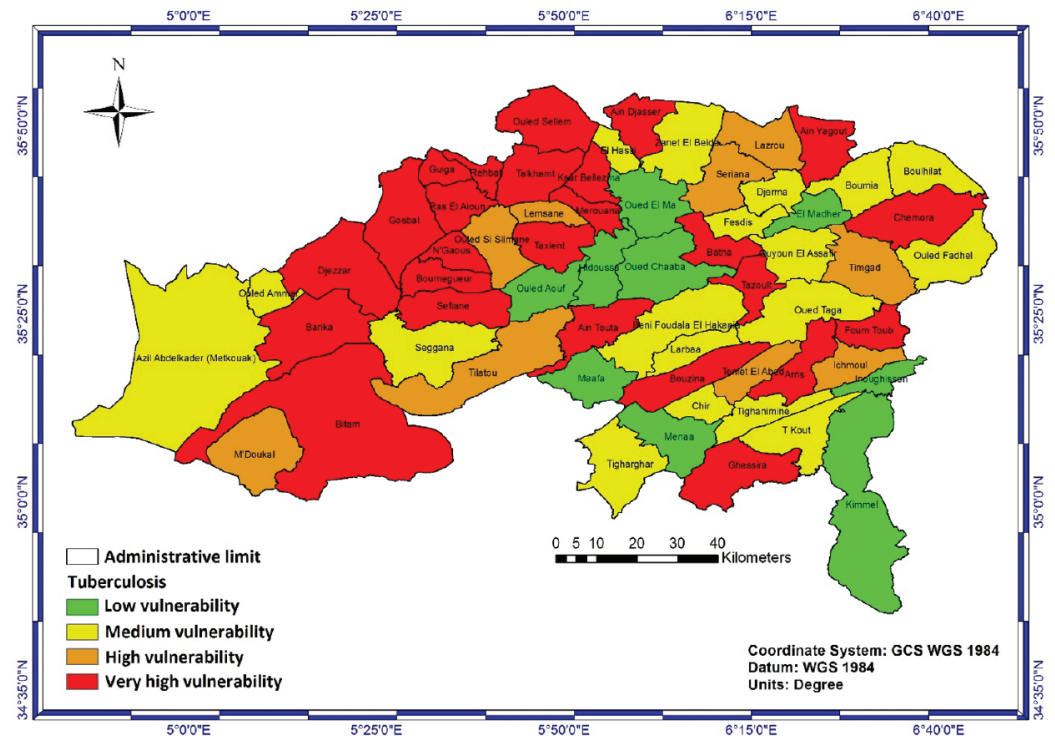

Source: Authors' own study

Fig. 8. Vulnerability to tuberculosis in the province of Batna

The previous figures (Fig. 8) indicate that the most vulnerable communes in Batna are commune of Batna; with all its urban inconsistencies, the municipality of Ain Touta and Tkout, with a whole string of municipalities who located in the North and West of the Wilaya with the socio-economic situation is still precarious and unstable. The rest of the municipalities show medium vulnerability to tuberculosis, especially in the east of the Wilaya. It should be mentioned that the municipalities located in the mountainous of the Aurès are the lowest vulnerable, due to the excellent quality of the air, and the environment, in general, is exceptionally clean.

It remains to check the relevance choice of the analyzed factors and the level of accuracy of the results. For this reason, the comparison of the map of vulnerability to tuberculosis with the map of declared cases of the disease shows a great similarity between the municipalities considered vulnerable according to our criteria of analysis and the municipalities locating the highest number of tuberculosis cases. This good similarity in our opinion is a validation of the analysis model and the results which result from it. 


\section{Conclusion}

Even if the majority of developed countries are close to eliminating the tuberculosis disease, this epidemic remains a scourge which still just alarming and remains an endemic-epidemic disease that constitutes a major public health issue in developing countries due to its nature, scale, and increasing spatial spread. Algeria is not an exception to this rule, there is an increase in tuberculosis number, this evolution is linked to the rhythm of the socio-economic state of this country. The Wilaya of Batna, is one of the territories who highly ranked by tuberculosis, the questions about the causal link with the factors of vulnerabilities reflecting the socio-economic and environmental reality of the territory. To fix the weight and the impact on the disease. The different parameters were subjected to a hierarchical multi-criteria analysis.

The multi-criteria analysis that we have adopted, and the results have been implemented in a GIS database, allow us to map the level of vulnerability in the entire territory of the Wilaya, comparing this with the map of declared cases of the disease establish a similarity between the vulnerability according to our analysis criteria and the municipalities locating the largest number of cases of tuberculosis.

At the end of this analysis, there is no doubt that tuberculosis is related to the economic and social conditions of people. Therefore, we adhere to the axiom that tuberculosis is the disease of poverty. The epidemiological situation in this wilaya inherent to the socioeconomic conditions in continuous deterioration, strongly and urgently required from authorities, scientists, and health professionals to take care of the situation. The highlighting of the numerous factors effectively involved in the level of vulnerability to tuberculosis, their interaction, and articulation on spatial-temporal scales give us a wider view to guide territorial actions of a preventive or curative nature. Indeed, the various causal factors identified and evaluated quantitatively will allow the decision-makers to choose the nature and extent of the actions to be undertaken and above all to define their priorities.

\section{Acknowledgements}

We thank the laboratory of Natural Hazards and Territory Planning for its help. We also thank DGRSDT (General Directorate of Scientific Research and Technological Development in Algeria) for its support, and the Health Direction of the Wilaya of Batna for facilitating access to data.

\section{References}

Aazri L., Aitbatahar S., Amro L. 2020. Facteurs de risques et diagnostic de la tuberculose. Revue des Maladies Respiratoires Actualités, 12(1), 264. https://doi.org/10.1016/j.rmra.2019.11.598.

Adeleke O.A., Fisher L., Moore I.N., Nardone G.A., Sher A. 2020. A Long-Acting Thermoresponsive Injectable Formulation of Tin Protoporphyrin Sustains Antitubercular Efficacy in a Murine Infection Model. ACS Pharmacology \& Translational Science, 4, 276-287. https:// doi.org/10.1021/acsptsci.0c00185.

Alihalassa S. 2018. Comprendre l'épidémiologie de la tuberculose en Algérie. Revue des Maladies Respiratoires, 35, A234-A235. https://doi.org/10.1016/j.rmr.2017.10.545. 
Amona M., Kokolo B., Loumouamou M., Mbita A., Ibata P. 2016. Impact of nutritional supplementation in lung disease tuberculosis recent discovery in Brazzaville, Congo. Médecine d’Afrique Noire, 63(09), 457-463. https://www.researchgate.net/publication/328729447.

Barrier G. 1994. Tuberculose et précarité. La prise en charge effective des urgences médicales. Rapport rendu au Premier Ministre sur la prise en charge préhospitalière des urgences, septembre 1994, dossier en santé publique, $\mathrm{n}^{\circ} 12$.

Baziz N. 2018. Contribution à la caractérisation et modélisation du cycle de l'eau potable et les risques associés dans la Wilaya de Batna (Approche par SIG) (PhD thesis). Université de Batna 2, Algérie, 6-41. http://eprints.univ-batna2.dz/id/eprint/1537.

Beale L., Abellan J.J., Hodgson S., Jarup L. 2008. Methodologic issues and approaches to spatial epidemiology. Environmental Health Perspectives, 116(8), 1105-1110. https://doi. org/10.1289/ehp.10816.

Boulahbal F., Chaulet P. 2004. La tuberculose en Afrique: Epidémiologie et mesures de lutte. Med. Trop., 64(3), 224-228.

Bruce A.T.I., Berra T.Z., Dos Santos F.L., Alves Y.M., Souza L.L.L., Ramos A.C.V., Arroyo L.H., de Almeida Crispim J., Pinto I.C., Palha P.F., et al. 2020. Temporal trends in areas at risk for concomitant tuberculosis in a hyperendemic municipality in the Amazon region of Brazil. Infectious Diseases of Poverty, 9, 1-14. https://doi.org/10.1186/s40249-020-00732-0.

Chakaya J., Khan M., Ntoumi F., Aklillu E., Fatima R., Mwaba P., Kapata N., Mfinanga S., Hasnain S.E., Katoto P.D. et al. 2021. Global Tuberculosis Report 2020. Reflections on the Global TB burden, treatment, and prevention efforts. International Journal of Infectious Diseases. https://doi.org/10.1016/j.ijid.2021.02.107.

Dangisso M.H., Datiko D.G., Lindtjørn B. 2015. Spatio-temporal analysis of smear-positive tuberculosis in the Sidama Zone, southern Ethiopia. PloS One 10, e0126369. https://doi. org/10.1371/journal.pone.0126369.

de Castro D.B., de Seixas Maciel E.M.G., Sadahiro M., Pinto R.C., de Albuquerque B.C., Braga J.U. 2018. Tuberculosis incidence inequalities and its social determinants in Manaus from 2007 to 2016. International Journal for Equity in Health, 17(187), 1-10. https://doi. org/10.1186/s12939-018-0900-3.

Elsheikh R.F.A., Ouerghi S., Elhag A.R. et al. 2015. Flood risk map based on GIS, and multi criteria techniques (case study Terengganu Malaysia). Journal of Geographic Information System, 7(04), 348-357. http://dx.doi.org/10.4236/jgis.2015.74027.

Fenniche K. 2018. Application du Processus Hiérarchique Analytique (AHP) a l'évaluation de la performance des banques commerciales. Les Cahiers du CREAD, 34(4), 39-59.

Furtado A. 2018. La surveillance du paludisme à Saint-Louis (Sénégal): comprendre les écarts entre morbidité réelle et 'morbidité compilée'. Espace populations sociétés Space populations societies (accessed: 2020 May 25). http://journals.openedition.org/eps/7607.

Habibi Y., Guellouh S., Filali A., Berchiche R. 2020. Analysis of social resilience to the novel coronavirus (Covid-19) in Algeria. Geomatics, Landmanagement and Landscape, 3, 19-29. http://dx.doi.org/10.15576/GLL/2020.3.19.

Harling G., Castro M.C. 2014. A spatial analysis of social and economic determinants of tuberculosis in Brazil. Health \& Place, 25, 56-67. https://doi.org/10.1016/j.healthplace.2013.10.008.

Hoffner S., Hadadi M., Rajaei E., Farnia P., Ahmadi M., Jaberansari Z., Velayati A.A. et al. 2018. Geographic characterization of the tuberculosis epidemiology in Iran using a geographical information system. Biomedical and Biotechnology Research Journal (BBRJ), 2(3), 213-2019. https://doi.org/10.4103/bbrj.bbrj_72_18.

Ifticene M., Kaïdi S., Khechiba M.-M., Yala D., Boulahbal F. 2015. Genetic diversity of Mycobacterium tuberculosis strains isolated in Algeria: Results of spoligotyping. International Journal of Mycobacteriology, 4(4), 290-295. https://doi.org/10.1016/j.ijmyco.2015.06.004. 
Kacem L., Agoussine M., Igmoullan B., Amar H., Mokhtari S., Ait Brahim. 2017. Application de la méthode d'analyse multicritère hiérarchique pour la quantification de perte en sol dans un sous-bassin montagnard-haute vallée de Tifnoute (Haut Atlas marocain). Geo-Eco-Trop, 41(3), 493-502.

Kalla M.I., Guettouche M.S. 2017. Using geomatics for assessing vulnerability to cutaneous leishmanisais. Application to the Wilaya of Batna (Algeria). International Journal of Geomate, 13(40), 9-15. https://doi.org/10.21660/2017.40.25868

MacNeil A., Glaziou P., Sismanidis C., Date A., Maloney S., Floyd K. 2020. Global epidemiology of tuberculosis and progress toward meeting global targets - worldwide, 2018. Morbidity and Mortality Weekly Report, 69, 281-285. http://dx.doi.org/10.15585/mmwr.mm6911a2.

Makhloufi M., Laouar L., Larbani B. 2017. Évolution de la situation épidémiologique de la tuberculose dans un secteur sanitaire d'Alger. Revue des Maladies Respiratoires, 34, A18-A19. https://doi.org/10.1016/j.rmr.2016.10.040.

Manneville P. 1995. La tuberculose en France et au Havre. Études Normandes, 44(4), 79-83. https://www.persee.fr/doc/etnor_0014-2158_1995_num_44_4_2215.

Mao Q., Zeng C., Zheng D., Yang Y. 2019. Analysis on spatial-temporal distribution characteristics of smear positive pulmonary tuberculosis in China, 2004-2015. International Journal of Infectious Diseases, 80, S36-S44. https://doi.org/10.1016/j.ijid.2019.02.038.

Mathieu P., Njoya I.M., Calba C., Lepoutre A., Marc E. 2019. Épidémiologie de la tuberculose en Île-de-France: une augmentation des cas déclarés en 2016 et en 2017. Revue de Biologie Médicale, N 351, 73-79.

Mouhoub W.A. 2020. Profil épidémiologique de la tuberculose dans une wilaya de l'est d'Algérie. Revue des Maladies Respiratoires Actualités, 12, 268. https://doi.org/10.1016/j. rmra.2019.11.609.

Organisation Mondiale de la Santé (OMS). 2014. Engage-TB: intégrer les activités communautaires de lutte contre la tuberculose dans le travail des organisations non gouvernementales et des autres organisations de la société civile: manuel de mise en oeuvre. WHO/HTM/ $\mathrm{TB} / 2013.10,2013$.

Organisation Mondiale de la Santé (OMS). 2018. Manuel d’enquête sur les coûts de la tuberculose pour les malades. Genève.

Organisation Mondiale de la Santé (OMS). 2019. Lutte contre le paludisme: surveillance, suivi et évaluation. Un manuel de référence. France.

Pelissari D.M., Diaz-Quijano F.A. 2017. Household crowding as a potential mediator of socioeconomic determinants of tuberculosis incidence in Brazil. PLoS One, 12, e0176116. https:// doi.org/10.1371/journal.pone.0176116.

Pereira A.G.L., Medronho R. de A., Escosteguy C.C., Valencia L.I.O., Magalhães M. de A.F.M. 2015. Spatial distribution and socioeconomic context of tuberculosis in Rio de Janeiro, Brazil. Revista de saude publica, 49, 48. https://doi.org/10.1590/S0034-8910.2015049005470.

Philippe F., Piton G., Tacnet J-M., Gourhand A. 2018. Aide à la décision par l'application de la méthode AHP (Analytic Hierarchy Process) à l'analyse multicritère des stratégies d'aménagement du Grand Büech à la Faurie. Revue Sciences Eaux et Territoires, (26), 54-57. https:// hal.archives-ouvertes.fr/hal-01927806.

Pruvost P., Rivalan B. 2014. Du risque transfrontalier vers une nécessaire réponse sanitaire et sociale communautaire: l'exemple de la tuberculose multi-résistante. Humanitaire Enjeux, pratiques, débats (37) 52-59. http://journals.openedition.org/humanitaire/2906.

Ramos A., Cunha L., Cunha P.P. 2014. Application de la Méthode de l'Analyse Multicritère Hiérarchique à l'étude des glissements de terrain dans la région littorale du centre du Portugal: Figueira da Foz-Nazaré. Geo-Eco-Trop, 38(1), 33-44. 
Reyes A., Hernández M., Delpiano L., Izquierdo G., Cofré F., Aravena M., Labraña Y., Sandoval A. et al. 2020. Tuberculosis: a challenge in newborn care and how to deal with it. Update document. Revista Chilena de Infectologia: Organo Oficial de la Sociedad Chilena de Infectologia, 37, 51-63. https://dx.doi.org/10.4067/s0716-10182020000100051.

Rimba A.B., Setiawati M.D., Sambah A.B., Miura F. 2017. Physical flood vulnerability mapping applying geospatial techniques in Okazaki City, Aichi Prefecture, Japan. Urban Science, 1(7). https://doi.org/10.3390/urbansci1010007.

Saaty T.L. 1987. The analytic hierarchy process. What it is and how it is used. Mathematical Modelling, 9(3-5), 161-176.

Saaty T.L. 2008. Decision making with the analytic hierarchy process. International Journal of Services Sciences, 1(1), 83-98.

Siddayao G.P., Valdez S.E., Fernandez P.L. 2014. Analytic hierarchy process (AHP) in spatial modeling for floodplain risk assessment. International Journal of Machine Learning and Computing, 4(5), 450-457. https://doi.org/10.7763/IJMLC.2014.V4.453.

Taglioni F., Dehecq J.-S. 2009. L'environnement socio-spatial comme facteur d'émergence des maladies infectieuses. Le chikungunya dans locéan Indien. EchoGéo. https://doi. org/10.4000/echogeo.11168.

Thébaud-Mony A. 1990. Inégalités sociales et tuberculose en Seine Saint-Denis dans les années 1980. Une recherche pluridisciplinaire en santé publique. Sociétés contemporaines, 3(1), 59-80. https://doi.org/10.3406/socco.1990.965.

Vachon J., Gallant V., Siu W. 2018. Can we eliminate tuberculosis? Tuberculosis in Canada, 2016. Canada Communicable Disease Report, 44, 75. https://doi.org/10.14745/ccdr.v44i34a01

Van Vooren J.-P., Schepers K., Wanlin M. 2010. La tuberculose pulmonaire. Revue médicale de Bruxelles, 31(4), 260-266.

Yazdani-Charati J., Mahaki B., Ahmadi-Basiri E. 2017. Identification of High and Low-Risk Areas of Tuberculosis in Lorestan Province, West of Iran. Tanaffos, 16(4), 270-276.

Yombi JC., Olinga U. 2015. La tuberculose: épidémiologie, aspect clinique et traitement. Louvain Med., 134(10), 549-559.

\author{
PhD Asma Douha \\ University of Batna 2 \\ Geography and Territory Planning Natural Hazards \\ and Territory Planning Laboratory, Algeria \\ e-mail: douha.asma3@gmail.com \\ ORCID: 0000-0002-1119-6710 \\ Prof. Mahdi Kalla \\ University of Batna 2 \\ Geography and Territory Planning, \\ Natural Hazards and Territory Planning Laboratory, Algeria \\ e-mail: mahdi.kalla@univ-batna2.dz \\ ORCID: 0000-0001-6380-8777
}

